\title{
2足剛体モデルを用いた歩行者による 歩道橋の水平励振に関する1つのシミュレーション
}

阿部雅人*・藤野陽三**

歩道橋が歩行荷重の動的な作用によって, 水平横方向に振動することがある. その現 象を，人間の歩行に対して 2 足剛体モデルを導入して検討している. このモデルによっ て計算された歩行に伴う水平横方向踏力は, 実測値と整合的であること, この現象が生 じている実橋を例にとって橋桁-人間系の応答解析を行い，奉橋での振幅に近い值を得 ている. さらに, この結果をもとに, 歩道橋の水平励振のメカニズムについて考察を加 えている.

Keywords : lateral vibration, pedestrian bridge, human walking, rigid body, phase lag, numerical study

\section{1.はじめに}

歩行力の動的作用によって桁に有意な水平横たわみ振 動が励起されることがある11,2). しかしながら，歩行に 伴亏踏力の水平成分は鉛直方向成分の 10 分の 1 程度と 小さく，歩行者が书互いに独立に歩いているとすると， この現象は説明できない11.

そこで, 関口ら²)は実橋での歩行者の動きを撮したビ デオ画像の解析結果から, また岡本ら ${ }^{31}$ は水平横振動す る床上での歩行実験によって，人間の歩行が床の振動に 同調する傾向が認められることを示した。これらの結果 から，文献1)～3）では，橋が何等かの原因で横方向に 振動し始めると，人の歩行は橋桁の動きに同調し，これ により橋桁の振幅が増え，さらに多くの人の歩行が同調 するという自励振動的な過程として, この振動を説明し ている.

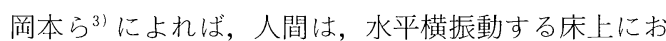
いて

(1) 歩行の振動数は床の振動数に近付く

(2) その際に，首の変位の位相は床の変位の位相より 180 度遅れる傾向にある. 踏力の水平横方向成分 は，首の変位より更に 30 度，床の動きからみれ ば 210 度程度遅れると見積られる

(3) 歩行者が床に加える水平横方向踏力は大きくなる という歩行特性を有することが明らかになった．

歩行者の踏力による橋析の共振ととらえれば，その位 相差は 270 度と考えるのが自然である。しかし，上に述 ベたように，両者の位相差は 210 度程度と見積られる。 このことは外力による単なる共振としては現象が説明で きず，橋桁と人間との動的相互作用を考えることの必要

\footnotetext{
*学生会員 東京大学大学院 土木工学専攻
}

( =113 東京都文京区本郷 7-3-1)

**正会員 $\mathrm{Ph} . \mathrm{D}$ 東京大学教授 工学部土木工学科
性を示唆している.

ここでは，人間の動きとしての 2 足剛体ロッキングモ

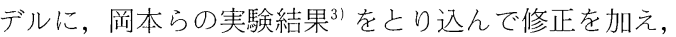
橋桁一人間系の動的相互作用のシミュレーションを実施 する. その結果に基づいて, 人間歩行に伴う桁の水平励 振メカニズムについての考察を行う.

\section{2. 人間の歩行のモデル化}

ここでは，橋梁の励振現象に直接関係のある，踏力を モデル化することを目標に，人間を剛体と考えたモデル を導入する。

\section{（1）人間の歩行特性}

人間の歩行特性については，義足の設計やリハビリ テーションへの応用のために医用工学の分野で詳しく調 ベられている，図一1は，佐藤ら”によって得られた踏 力の実測波形である. 横軸は時間であり, $T$ は歩行の周 期， $d$ は両足で支持している時間である。縦軸は人間 の体重を 100 上して無次元化されている. 鉛直方向踏力 は体重のオーダーであり, 水平横方向踏力は体重の 1 割 程度のオーダーであることがわかる.

\section{（2）人間の歩行のモデル化}

人間の動作は，骨格や筋肉，神経系などが絡み合った 複雑な現象であると考えられる。しかし，歩行のような 日常的な運動については，重力の作用をできるだけ利用 して，筋力の負担を小さくするような効率的な運動がな されていると思われる．極端な場合として筋力を全く使 わない運動を想定すると,重力をうける剛体運動となる. そこで，筋力の働きが小さいとして，人間の歩行を剛体 運動によってモデル化することを考える．図一2のよう な質点と質量のない 2 本の脚を持つ簡単な剛体の運動で 歩行時の人間の挙動をとらえてみる。ここでは, 水平横 振動に伴う横方向の踏力が問題になるので，前進せずそ の面内で横方向に起き上がりこぼしのように振動するも 


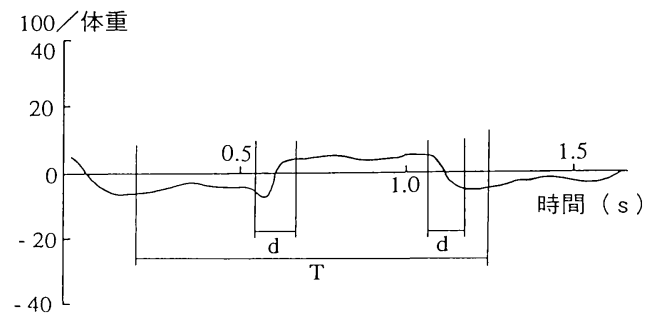

a）水平横方向成分

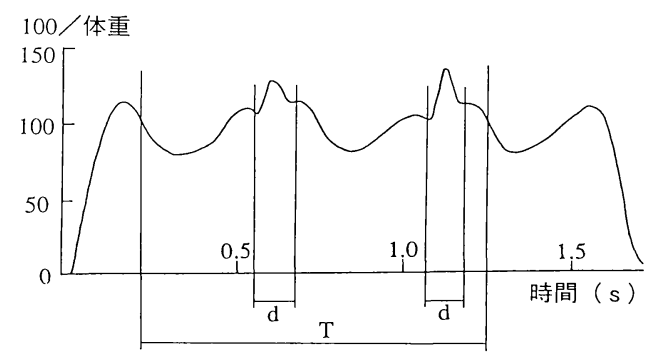

b）鉛直方向成分

図一1 測定された踏力成分 ${ }^{4)}$

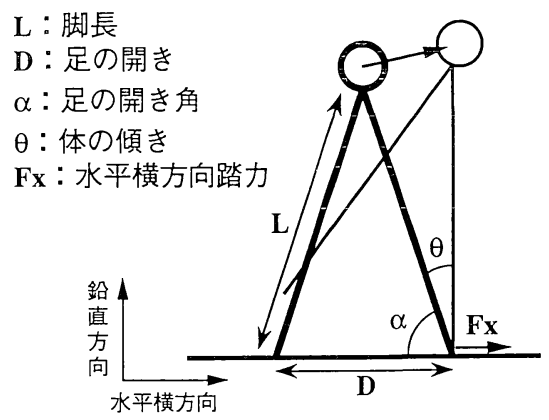

図一2 人間の歩行のモデル

のよする. 図一2のモデルの運動方程式は，以下のよう になる。

$L \ddot{\theta}=-\operatorname{sgn}(\theta) \cdot g \cdot \cos (\alpha+|\theta|)$

ここに, $g$ : 重力加速度 $\left(=980 \mathrm{~cm} / \mathrm{s}^{2}\right), L$ : 脚長 $(=$ $85 \mathrm{~cm}), D$ : 脚の開き $(=20 \mathrm{~cm}), \alpha$ : 足の開き角 $(=$ $\arccos (D /(2 \cdot L))), \theta:$ 体の傾き, $\operatorname{sgn}(\theta): \theta$ の符号 である

但し， $\theta$ は右に倒れているときを正，左に倒れている ときを負とする．以下に挙げる図では， $\theta$ を静的な状態 でこのモデルが転倒する限界を与える $\theta_{0}=(\pi / 2)-\alpha$ で 除して， $\theta / \theta_{0}$ で無次元化して表示する。なおここでの 脚長 $L$ は，重心までの高さをモデル化したものである ので，実際の脚長よりは多少長めの值をとった。

左右の足が床に着く現象は一種の衝突現象であり,こ の時に運動量の損失があると考えられる.ここでは，方 程式（1）において, $\theta$ の正負が切り替わる際に, 角運 動量が $c$ 倍になるとして $(0 \leqq c \leqq 1)$, その損失をモデル

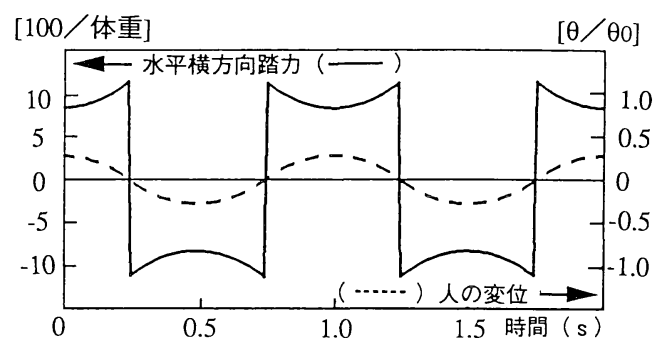

a) 水平横方向

[100/体重 $]$

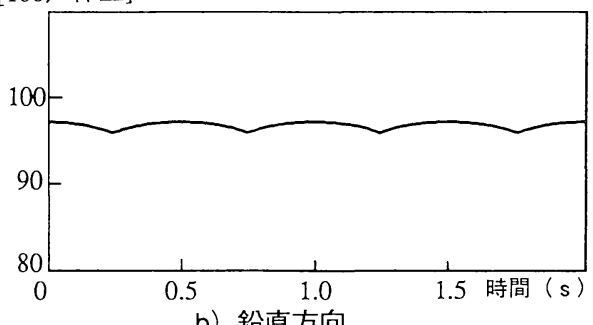

直方向

図一3 自由振動時の踏力成分

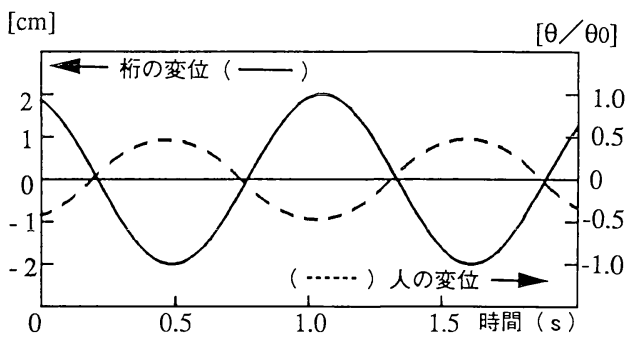

図-4 強制振動時の桁と人の変位

化する. $c$ の值は，この岡体モデルが転倒しないことと， 歩行が減衰してしまわない（歩行を止めない）ことを条 件にして, 経験的に決定した.このパラメータは, 倒れ ずに歩き続けるための人間の意志や，筋力の働きなどの 諸々の複雑な作用をモデル化したものと考えている.

このモデルを $c=1.0$ として数值積分により求めた非 減衰自由振動波形が，図一3である. 水平方向の踏力を 見ると, このモデルでは, 両足共に着地している時間が ないので, その分, 力の切り替わり方が実際よりも急に なっているものの，力の大きさ，波形とも図一1 a）之 かなり良く合っているといえよう。このような簡単なモ デルでも, 人間の水平横方向の踏力の推定に用いるのが 妥当であることがわかる.

鉛直力については, 大きさのオーダーは合っているが, 足がついている間の波形が上に凸な計算結果となってお り，下に凸な実際の波形（図一1 b ））とかなり異なった 波形になっている．また，実際の波形よりかなり変動が 小さい.この相違は，このモデルでは前進することによ る遠心力の影響が考慮されていないためである。この影 
$\mathrm{m} ：$ 歩行者の有効質量

$\mathbf{M}:$ 桁の有効質量

$\mathbf{h}$ : 桁の減衰比

$\omega:$ 桁の固有円振動数

$\mathrm{X}:$ 桁の変位

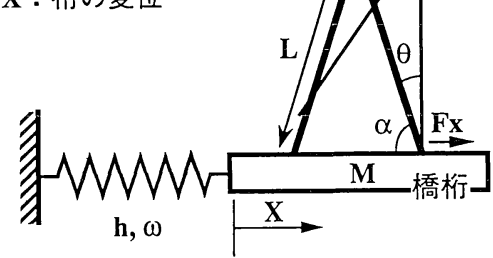

図一5人間と橋桁の相互作用のモデル

響を考慮に入れると，下に凸な波形が得られる51.

振幅 $2 \mathrm{~cm}, 0.9 \mathrm{~Hz}$ で正弦変位する床上でのこのモデ ルの挙動を計算したのが図一 4 である. $c$ の值は 0.95 之 した．強制振動であるので，その振動数は完全に床の振 動数に同調する．その変位の位相差は 180 度となってお り，人の首の動きと重心の動きとの位相差が小さいとす れば，前述の岡本らによる実験結果(1) (2)に整合する. すなわち，これらの実験結果は，人間が単に剛体のよう に振られているということで説明がつく。また，これは 実橋における橋桁と頭の動きとの位相関係 ${ }^{1,2)}$ とも整合 的である.

\section{3. 人間と橋桁の相互作用}

2.（2）でも述べたように，図一2のような簡単なモ デルでも，水平横振動する床上での人間の運動をうまく 説明できる．橋桁との相互作用を考える際には，水平横 振動する床上での踏力が問題になるが，先にも挙げたよ うに，岡本ら ${ }^{3)}$ の実験によればその踏力は首の動きより 位相が遅れる。この実験結果に基づき，図一2に挙げた 歩行者のモデルに，踏力が首の動きより位相差 $\phi$ 遅れ るという条件を加えたものを，相互作用の検討の際の歩 行者モデルとする.

水平横振動する床上で安定に歩き続けることを考える と,筋力の働きが通常時よりも重要になると考えられる. 著者らはその筋力のある種の働きを位相差 $\phi$ という形 で剛体モデルにとりこんでいると解釈しているが，その 人間工学的な意味は，今のところ明確になっていない.

以上の議論より，橋桁との相互作用の方程式は以下の ようになる（図一5）。

$$
\begin{aligned}
& L \ddot{\theta}=-\operatorname{sgn}(\theta) \cdot g \cdot \cos (\alpha+|\theta|)-\ddot{X} \sin (\alpha+|\theta|) \cdots(2) \\
& \ddot{X}+2 h \omega \dot{X}+\omega^{2} X=\frac{m}{M} F_{x}(t-\tau) \cdots \cdots \cdots \cdots \cdots \cdots \cdots(3) \\
& F_{x}(t)=-L \ddot{\theta} \sin (\alpha+|\theta|) \\
& \quad-\operatorname{sgn}(\theta) \cdot L \dot{\theta}^{2} \cos (\alpha+|\theta|)-\ddot{X} \cdots \cdots \cdots \cdots(4) \\
& \text { ここに, } x: \text { 橋桁の変位, } h: \text { 橋枌の減衰比, } \omega: \text { 橋桁 }
\end{aligned}
$$

[cm]

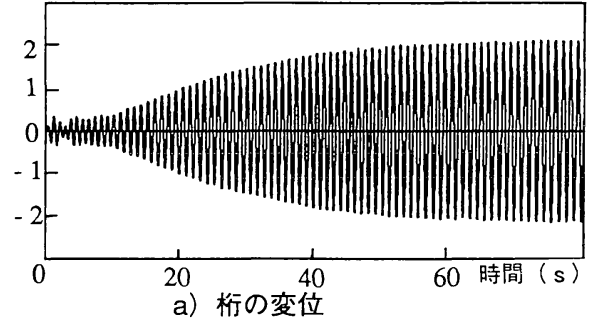

振動数 $(\mathrm{Hz})$

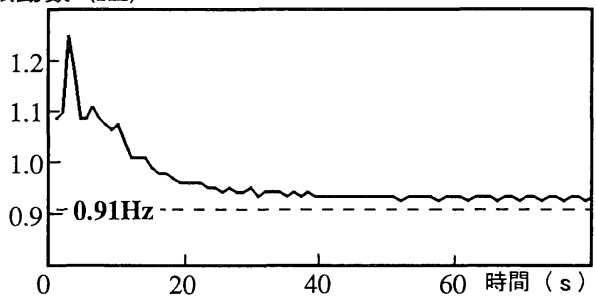

b) 栴の振動数の変化

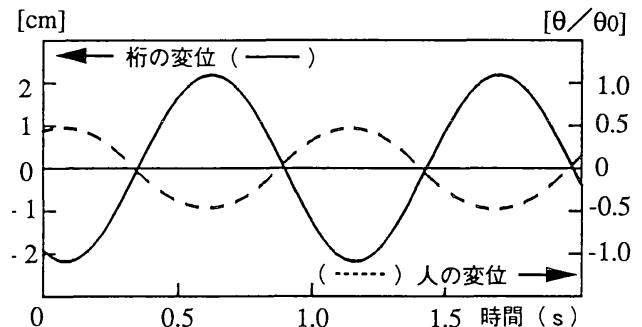

c）桁と人の変位

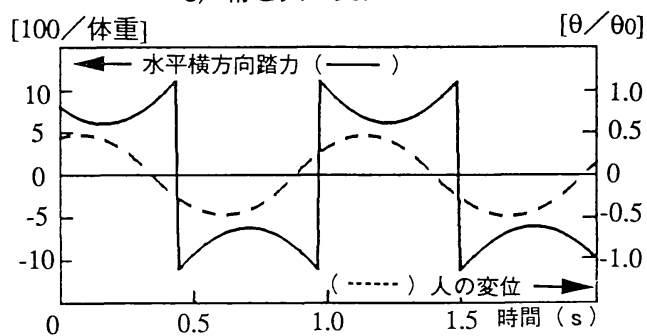

d）水平横方向踏力

図一6 相互作用のシミュレーション結果

の固有円振動数, $M$ : 橋桁の有効質量, $m$ : 人の有効質 量, $F_{x}$ : 単位質量あたりの水平横方向踏力, $t$ : 時間, $\tau$ : 人の動きと水平方向踏力の位相差 $(=\phi)$ に対応する 時間遅れであり，その他の記号は式 (1) と同様である.

この方程式を, 高密度の群衆の通過によりピーク時で $1 \mathrm{~cm}$ を超える水平横振動が観測された歩道橋 ${ }^{1)}(\omega / 2 \pi$ $=0.91 \mathrm{~Hz}, h=0.01$, 有効モード質量 $200 \mathrm{t} ）$ に適用し てみる.ここで，橋梁上の歩行者（2000人）の 20 パセントが完全に同調しているとして，他の歩行者の踏力 は互いにランダムで打ち消し合うとする ${ }^{11,21}$. このとき, 式（3）における $m / M$ は, 1 人当りの質量を $60 \mathrm{~kg}$ と しモード形状による補正係数を $1 / 3$ とすれば 0.04 とな 
る.その他の条件を式 $(1)$ を計算した際と同じにし, cの值も前と同じ 0.95 とする.また， $\phi$ の值としては， 岡本らの実験結果より 30 度とした. $\theta$ にのみ初期変位 を与えて計算した結果が図一6である. $\theta$ の初期值は,

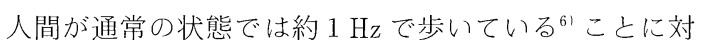
応して, 人間モデルが自由振動状態で $1 \mathrm{~Hz}$ で振動する 初期値を用いている.

図一 6 a）にみるように，このような人間と橋桁の連 成系は橋桁に大振幅の横振動をもたらす。図一6b) は 桁の 1 波ごとの振動数をとったものである.これをみる 亡摇れはじめは振幅が小さく振動数が高いが, 振幅が大 きくなっていくにつれて振動数は桁の固有振動数である $0.91 \mathrm{~Hz}$ に近付く.この振動数の変化する現象は, 実橋 においても観測されている.

定常状態 (図一 $6 \mathrm{c}), \mathrm{d}))$ をみると, 橋桁と人の動き が逆位相になっている. また，定常状態で橋桁にして 2 $\mathrm{cm}$ 程度の振幅を与えている.これは, 実橋の振幅レベ ルのオーダーになっている.

\section{4. 現象についての考察とまとめ}

人間の運動モデルとして 2 足剛体モデルを考え,

(1)「通常時の歩行は, 重力ポテンシャル下での成体の ロッキング自由振動としてとらえてもよいこと」を確認 した上で, (2)「振動床上での歩行運動モデルには, 安定 した歩行を行うために，定数 $c$ ，および夹験結果をべ一 スにした頭と踏力との位相差 $\phi$ のつのパラメータを 導入し」, 橋桁と人間歩行系との動的相互作用シミュレ一 ションを実施した. なお, 定数 $c$ および位相差 $\phi$, 特に $\phi$ の人間工学的な意味については詰めるべき点が多い が，予測振幅はほぼ実橋と整合的な値となった。

このモデルを用いて改めて歩行者による歩道橋の水平 励振メカニズムを説明すると以下のようになる.

「歩行踏力の水平卓越成分は $1 \mathrm{~Hz}$ 前後にあるので, 橋 の水平固有振動数がこの付近にあると, 小振幅の水平振 動が励起される.この水平振動によって, 歩行者は奧体 ロッキングのように振り回されるので, 橋枌の振動と逆
の位相に同調しやすくなる.ここで, 人問が倒れずに歩 き続けようとする際に，筋力の働きによって踏力が体の 重心の動きよりも遅れ気味に橋桁に作用する.この位相 差を持った加振力が水平振動を増大させる. 振幅の増大 に伴い, 振動数は橋桁の固有振動数に引き込まれていく. そして, 更に大振幅の振動に成長していく.」

なお，ここで用いた剛体のモデルでは，橋桁の振動数 によらず歩行が橋桁の振動に同調することになる.とこ ろが, 実際には固有振動数が $1 \mathrm{~Hz}$ 近傍の橋梁でしかこ のような現象は観測されていない. したがって, 実際の 人間には，同調する振動数の範囲があると考えられる。 また、ここでは、最初から2割の人が足をそろえて歩く として計算しているが、実際には個々の人によって振動 への感受性が異なることから、振幅が大きくなるにつれ てより多くの人が同調していく意味での自励振動的メ力 二ズムも有していると思われる.このような個々の人間 の振動への感受性にかかわる問題は, 今後の課題であろ う.

\section{参 考 文 献}

1) Pacheco, B. and Fujino, Y. : Synchronization of human walking observed during lateral vibration of a congested bridge, Proc. of 6th US-Japan Bridge Engineering Workshop, pp.449 462, Nevada, USA, May, 1990.

2) 関口 $\cdot$ Warnitcha1, P. · Pacheco, B. ·藤野·伊藤：人 の歩行特性之橋の横方向励振可能性, 土木学会第 45 回年 次学術講演会講演概要集第 1 部, pp. 20 - 21, 1990 年 9 月.

3) 岡本・阿部・藤野 ·中野 : 水平横振動する床上での人の 歩行特性, 土木学会論文集, No. 441, pp. 177 184, 1992 年 1 月.

4) 佐藤正視・真武友一：大型踏力計による健常者の歩行特 性の解析, 日本機械学会諭文集 (C 編), Vol. 55, No. 518 号, pp. 2672 2675, 1989 年 10 月.

5) Alexander, R.M. : Walking and Runnning, American Scientist, Vol.72, pp.348 354, 1984.

6）松本・佐藤・西岡・塩尻：歩行者の特性を考慮した歩道 橋の動的設計に関する研究, 土木学会論文報告集, No. 205, pp. 63 70, 1972 年 9 月.

(1991.5.8 受付)

\title{
A SIMULATION ON PEDESTRIAN-INDUCED LATEAL VIBRATION OF A BRIDGE USING A TWO-LEGS HUMAN MODEL
}

\section{Masato ABE and Yozo FUJINO}

\begin{abstract}
Pedestrian-induced lateral vibration of a bridge is studied using a two-legs rigid rocking model for human walking. Lateral force exerted by walking is calculated by this model and is found to agree with the experimental data. A bridge where lateral vibration is observed is chosen as a case study. Interaction between human walking and the girder is studied using the model under the assumption that there is a phase lag between human motion and walking force. The calculated amplitude of the girder is as the same order as of that bridge. According to these results, the mechanism of pedestrian-induced vibration is also discussed as an interaction of human and girder.
\end{abstract}

